\author{
Patrycja Chlebus-Grudzień \\ Uniwersytet Jagielloński \\ Wydział Filozoficzny \\ Instytut Socjologii \\ patrycja.chlebusgrudzien@gmail.com
}

\title{
SELFIE W MUZEUM - OKREŚLENIE PARADYGMATÓW ANALIZY ZJAWISKA FOTOGRAFOWANIA (SIĘ) NA WYSTAWACH MUZEALNYCH
}

\begin{abstract}
Abstrakt: Dzięki rozwojowi mediów społecznościowych coraz popularniejsze staje się udostępnianie zdjęć, często w formie tzw. selfie. Zjawisko fotografowania samego siebie pojawiło się w instytucjach kultury, w tym także w muzeach. Placówki wypracowują różne strategie reagowania na fotografowanie się na tle eksponatów. W artykule dokonano analizy tych reakcji, a na ich podstawie wskazano zróżnicowane sposoby definiowania funkcji oraz roli współczesnego muzeum. Spróbowano także odpowiedzieć na pytanie, czy udostępnienie zdjęć przez zwiedzających jest elementem tworzenia ich własnego wizerunku (kultura narcyzmu), czy raczej interakcji z dziedzictwem, dialogu z prezentowanymi treściami (kultura remiksu).
\end{abstract}

Słowa kluczowe: selfie, muzeum, fotografia turystyczna, kultura narcyzmu, kultura remiksu.

\section{WSTĘP}

Fotografowanie się na wystawach muzealnych jest coraz popularniejszym zjawiskiem i dlatego coraz częściej komentowanym zarówno przez muzealników, jak i samych zwiedzających. Zaczyna być tak znaczące społecznie, że warto uczynić je przedmiotem analizy naukowej. Jednak specyfika tego fenomenu sprawia, że brakuje narzędzi, a co może istotniejsze, kategorii analitycznych do opisywania oraz badania prywatnych fotografii $z$ wystaw. Celem autorki niniejszego artykułu jest więc przede wszystkim wpisanie tematyki zdjęć osób zwiedzających muzea w szerszy kontekst rozważań socjologicznych, dotyczących fotografii i jej związków z turystką, a także wyodrębnienie perspektyw i sposobów analizy przydatnych do projektowania badań. Takie opracowanie pozwoli unikać banalizacji i powierzchowności rozważań, które często wkradają się $\mathrm{w}$ naukowe wywody $\mathrm{w}$ sytuacjach, gdy dotyczą one zjawisk związanych z nowymi technologiami czy mediami społecznościowymi. Artykuł ma charakter analizy eksploracyjnej, która porządkując tematykę, stanie się podstawą do przyszłego konstruowania skutecznych i efektywnych narzędzi badawczych.

\section{OPIS ZJAWISKA}

Portale społecznościowe stają się przestrzenią nieustannego udostępniania i rozpowszechniania doświadczeń, podejmowanych rodzajów aktywności czy zdarzających się sytuacji - najczęściej $w$ formie zdjęć użytkowników. Wśród publikowanych fotografii można odnaleźć również takie, które zostały wykonane w obiektach muzealnych. Użytkownicy chwalą się za ich pomocą swoimi wizytami $\mathrm{w}$ tych placówkach. Prezentują się na tle dzieł sztuki, fotografują się z eksponatami, relacjonują zwiedzanie wystaw. I chociaż aparat fotograficzny nie jest nowym narzędziem w muzeum - pomaga np. dokumentować posiadane zbiory - to udostępnianie przez odwiedzających zdjęć w Internecie uznawane jest przez wielu za zaskakujące zjawisko, za zachowanie, które nie wpisuje się $\mathrm{w}$ tradycyjne wyobrażenia o zwiedzaniu muzeów. Przez długi czas, gdy turyści wykonywali zdjęcia, trafiały one do ich domowych kolekcji, stawały się prywatnymi pamiątkami, pokazywanymi w kręgu rodzinnym i towarzyskim. Obecnie dostęp do turystycznych fotografii z muzeów znacznie się poszerzył. Osoby dzielą się wrażeniami ze swoich wizyt w muzeach, najczęściej nie ograniczając liczby potencjalnych oglądających. 
Zdjęcia w portalach społecznościowych nie są już tylko osobistymi obrazami wywołującymi wspomnienia, ale stają się częścią szeroko rozpowszechnianego wizerunku.

Zwiększająca się liczba publikowanych fotografii, przedstawiających osoby w czasie wizyt w muzeum, pozwala stwierdzić, że jest to zjawisko, którym powinni się zainteresować zarówno muzealnicy, jak i badacze. Obecnie w portalu Instagram ${ }^{1}$ znajduje się 11258653 zdjęć oznaczonych hasłem \#museum, \#muzeum pojawia się w opisach 133957 fotografii (dane z listopada 2017 r.). Także konkretne placówki można spotkać jako obiekty zaznaczane w publikowanych postach (np.: \#uffizi - 127101 fotografii, \#metropolitanmuseumofart - 197 293, \#britishmuseum - 336 656, \#louvre - 1905 462). Liczby te wskazują, że opisywane przypadki nie stanowią marginalnych i jedynie jednostkowych zachowań. Oczywiście wiele atrakcji turystycznych znacznie częściej staje się tematem publikowanych zdjęć, jednak wizyty w muzeach zaczynają być doświadczeniami, którymi użytkownicy w coraz większym stopniu chcą dzielić się z innymi. Na rosnącą popularność tego zjawiska mają wpływ celebryci, gdyż oni także publikują relacje np. z odwiedzanych wystaw (Beyoncé, Kim Kardashian i in.). Przyglądając się różnym sposobom spędzania czasu wolnego, demonstrowanym w portalach społecznościowych, można stwierdzić, że zwiedzanie ekspozycji traktowane jest przez użytkowników jako codzienne zachowanie.

W wielu przypadkach odwiedzanie muzeów przedstawiane jest jako naturalna konsekwencja zwiedzania nowego miasta lub spędzania wolnych chwil. Ani osoby udostępniające, ani komentujące nie opisują tych wizyt jako nadzwyczajne wydarzenia dostępne dla nielicznych. Zdjęcia z różnych placówek muzealnych znajdują się wśród innych, takich jak: wyjścia do restauracji, kina czy na koncert. Instytucje muzealne zaczynają być dzięki temu rozpoznawalne, stają się częścią internetowej codzienności. W tym miejscu należy podkreślić, że wystawa tak naprawdę zachęca do wykonywania zdjęć w większym stopniu niż inne formy rozrywki czy edukacji. Muzea z natury rzeczy są wizualne. Mają zaaranżowaną przestrzeń, w której przebywają odwiedzający. Przypomina to poniekąd scenografię: wykreowany, specjalnie przygotowany świat, który tylko czeka, aby go uwiecznić. Na wystawach prezentowane są unikatowe, atrakcyjne obiekty, eksponowane w bardzo przemyślany sposób. Zwiedzający, wchodząc do sali z ekspozycją, nie muszą stwarzać sytuacji na tyle ciekawej, aby była warta uchwycenia. Znajdują się oni bowiem w miejscu, które już spełnia to kryterium. Cała wystawa składa się z dobrze wyglądających i potencjalnie ciekawych scenerii. Do odwiedzających należy tylko wybór tego, na co zwrócą uwagę, co sfotografują oraz czym podzielą się z innymi użytkownikami Internetu.
Muzealnicy dostrzegają rosnącą popularność publikowania zdjęć. Sami opisują zachowania gości, którzy fotografują się z eksponatami. Jedni reagują na to z zadowoleniem, widząc w tym zjawisku możliwość skutecznej promocji placówek oraz sposób na zainteresowanie publiczności dziedzictwem kulturowym, inni zdecydowanie krytykują, podkreślając kwestię fizycznego zagrożenia eksponatów oraz zbanalizowania tematów podejmowanych na wystawach.

Ł. MAŹNICA (2016) wyodrębnił cztery strategie przyjmowane przez instytucje muzealne: 1) negacja, 2) względna bierność, 3) akceptacja w kontrolowanych ramach i 4) entuzjazm. Pierwsza przejawia się całkowitym zakazem robienia zdjęć w obrębie wystawy. Druga polega na przyzwoleniu na fotografowanie pod warunkiem przestrzegania obostrzeń, np. nieużywania kijów do zdjęć typu selfie. Trzeci typ reakcji odnosi się do sytuacji, gdy przy jednoczesnym zakazie stworzone zostaje miejsce z replikami eksponatów, służące do wykonywania zdjęć - pozwala to unikać zagrożenia uszkodzenia oryginalnych dzieł czy przedmiotów. Entuzjazm z kolei oznacza nie tylko przyzwolenie, lecz również zachętę do wykonywania i publikowania fotografii, m.in. poprzez internetowe akcje czy konkursy na najbardziej interesujące zdjęcie z muzeum. Sposób reakcji placówki z pewnością wskazuje na to, jak definiuje ona swoje zadania oraz jak postrzega komunikację z publicznością.

\section{SPOLECZNE ZNACZENIE WYKONYWANIA ZDJĘĆ}

Zjawisko fotografowania się w muzeum, chociaż rozpoznane i szeroko dyskutowane, nadal traktowane jest często $\mathrm{z}$ pewną pobłażliwością, uznawane za modę, której nie warto poświęcać naukowej refleksji. Jednak analiza fotografii publikowanych w Internecie może doprowadzić do wzbogacenia wiedzy na temat mechanizmów współczesnej komunikacji lub odbioru kultury. W niniejszej pracy autorka chciałaby zastanowić się nad tym, w jakich dziedzinach badanie udostępnianych fotografii $\mathrm{z}$ muzeum może okazać się przydatne, jakimi kategoriami można opisywać to zjawisko, a także $\mathrm{z}$ jakich perspektyw można je analizować. W rozważaniach teoretycznych oraz w badaniach nad takimi zachowaniami należy z pewnością pamiętać, aby nie postrzegać zdjęć w Internecie $\mathrm{w}$ oderwaniu od innych rodzajów fotografii. Nie są one zupełnie nowym, odmiennym i nieodkrytym tworem, lecz wynikają z dawno już istniejącej potrzeby fotografowania oraz oglądania powstałych obrazów. Dlatego na początkowym etapie ich analizy tak istotne jest określenie społecznego znaczenia wykonywania zdjęć. 
Aparat służy do dokumentowania, wyodrębniania jednej chwili z wielu innych i przetwarzania jej na konkretny, stały obraz. Określona sytuacja zostaje $\mathrm{w}$ tym procesie utrwalona, ma swoją reprezentację. K. KONECKI (2005) nazywa wręcz fotografie „protezami pamięci". Stwierdza on, że "fotografując, tworzymy określony obraz w teraźniejszości dla przyszłości z tego, co wkrótce będzie przeszłością". Zdjęcie jest świadectwem minionej chwili, tworzy łatwo dostępne środki do budowania narracji o przeszłości. Utrwalony obraz (czy to w fizycznej, czy w cyfrowej formie) odsyła do ludzkich przeżyć. Należy bowiem pamiętać, że aparat jest narzędziem, które nierozerwalnie łączy to, co fotografowane, $\mathrm{z}$ osobą wyzwalającą migawkę. Chociaż na pierwszy rzut oka widoczne jest tylko to, co na zdjęciu, każdy kadr przedstawia bardzo subiektywną perspektywę danego człowieka. W literaturze wskazuje się na na iluzoryczną obiektywność zdjęć (BOURDIEU 2012, SONTAG 2017). Fotograf nie jest bierny, nie uruchamia aparatu bezrefleksyjnie, tworząc wierne odwzorowania rzeczywistości. Zdjęcie nie pozwala na bezstronne i neutralne poznanie (chociaż tworzy pozory takiej sytuacji). Zdjęcie zawsze jest interpretacją, zarówno poprzez decyzję o przedmiocie fotografowania, jak również o sposobie jego przedstawienia.

Wykonywanie fotografii można określić jako proces dokonywania wyboru. Tak zwyczajna czynność jak używanie aparatu wiąże się z zaprezentowaniem swojego sposobu postrzegania, ze stworzeniem własnej wizji danego wydarzenia, osoby czy obiektu. F. SoULAGES (2007), opisując problematykę prywatnych zdjęć, ukuł termin „fotograficzne cogito". Autor wiąże czynność fotografowania z zaznaczeniem swojej obecności, podkreślaniem własnego istnienia. Ukazuje on, że prywatne zdjęcie „wydaje się być nie tylko świadkiem, ale przede wszystkim dowodem naszego życia, metamorfozą banalnego i anonimowego istnienia w takie, które zasługuje na bycie przeżytym" (SOULAGES 2007). Osoba robiąca zdjęcie wyraża niejako stwierdzenie: „Byłam i doświadczyłam”. Fotografie mają również zdolność nadawania wartości treściom na nich prezentowanym. To, co ujęte $\mathrm{w}$ formie zdjęcia, odbierane jest jako znaczące i ważne, gdyż ktoś to zauważył, uznał za ciekawe i zdecydował się utrwalić. Wybór wpisany w ten proces sprawia, że za pomocą aparatu osoby mogą określać, co jest warte oglądania i zapamiętania, a także co powinno być ukryte i niepokazywane.

Oprócz niezwykle istotnego aktu twórczego w fotografię wpisuje się również jej odbiór. Zdjęcie jest przekazem, medium w procesie komunikacji. Wykonuje się je przecież po to, aby coś przedstawiało. Nawet jeżeli nie zostaje stworzone, żeby się nim dzielić, to i tak staje się potencjalnym nośnikiem idei. Co ważne, nie zawsze fotograficzny przekaz zostaje odczytany zgodnie z intencją autora. Często zdjęcie wyrwane z pierwotnego kontekstu może tworzyć nowe zna- czenia i interpretacje. Warto też wspomnieć o więziotwórczej funkcji zdjęć. M. PIEJKO (2008) wskazuje wiele praktyk odbywających się wokół fotografii (wspólne wykonywanie zdjęć, oglądanie albumów, przesyłanie zdjęć, umieszczanie ich w ważnych miejscach), które pomagają utrzymać kontakt oraz tworzyć wspólną tożsamość. Najbardziej widoczne jest to w rodzinach, ponieważ fotografie, na których uwieczniono razem spędzone chwile lub tylko osoby najbliższe, często stają się osią wspólnie snutych opowieści. Także w kręgach towarzyskich można zauważyć podobne zachowania. Powyższa charakterystyka fotografii (jej specyfika, konsekwencje oraz funkcje) odnosi się również do zdjęć umieszczanych w Internecie. One także, dokumentując przeszłość, stają się podstawą pamięci, świadczą o istnieniu fotografa oraz jego selektywności. Mają też zdolność do nobilitowania, nadawania istotności danym sytuacjom oraz pełnią funkcję komunikacyjną i więziotwórczą.

Warto także podkreślić, że aparat „uprzywilejowuje", pozwala wartościować sytuacje, ale także je modyfikować. S. SONTAG (2017) opisuje to takimi słowami: „Fotografia ma prawo zakłócać, wdzierać się albo ignorować wszystko, cokolwiek się dzieje”. Osoba $\mathrm{z}$ aparatem w dłoni zyskuje lepszy dostęp do wydarzeń, umożliwia się jej bliższe podejście, zasłonięcie widoku innym. Logika uprzywilejowanego fotografa zaczyna być naturalnie przyjmowana przez coraz większą liczbę osób. Fakt wykonywania zdjęcia, w ich mniemaniu, uprawnia do naruszania obowiązujących obostrzeń. Może to rodzić napięcia, gdy zwiedzający, będący w amoku fotografowania, pojawią się w miejscu, w którym inne wartości przedkłada się nad potrzebę wykonywania zdjęć, np. w muzeum. Eksponaty nie potrzebują bowiem potwierdzenia wyjątkowości ze strony zwiedzających, uzyskały ją poprzez umieszczenie na wystawie. Muzealnikom nie zawsze zależy, aby to goście fotografowali wystawę. Placówki muzealne, chcąc zachować szacunek do eksponowanych dzieł czy przedmiotów, narzucają, aby dostęp do nich był ograniczany.

\section{DOMINACJA FOTOGRAFII A TURYSTYKA}

Wszelkie próby redukowania liczby fotografujących są współcześnie mocno utrudnione. Kłócą się bowiem $\mathrm{z}$ pojawiającymi się $\mathrm{W}$ społeczeństwie tendencjami, które w coraz większym stopniu uprzywilejowują obraz. Kultura wizualna jest opisywana jako dominująca, przez co wykonywanie zdjęć staje się czynnością naturalną, powszechnie akceptowalną, a nawet masową. Można określić ją jako niepodważalną normę. M. Bogunia-BorowsKA i P. SZTOMPKA (red. 2012) 
zauważają, że: „Dzisiaj wszyscy jesteśmy fotografami. Pośród wielu ról, które odgrywa współczesny człowiek, rola fotografa, kreatora obrazów wydaje się jedną z kluczowych dla istnienia w społecznym uniwersum świata. [...] Bycie fotografem życia społecznego oznacza nie tylko fizyczne wykonywanie zdjęć, ale również postrzeganie rzeczywistości obrazowo, poprzez kadry, wycinki i fragmenty rzeczywistości". Wizualne reprezentacje traktowane są $\mathrm{z}$ większym zainteresowaniem i uznaniem, to one głównie wpływają na społeczne wyobrażenia oraz zachowania. M. BOGUNIA-BOROWSKA i P. SZTOMPKA (red. 2012) wskazują pięć przejawów kultury wizualnej. Piszą, że mamy do czynienia ze społeczeństwem:

a) ikon - duże nasycenie życia codziennego wrażeniami wizualnymi; powszechnie występujące obrazy w bardzo zróżnicowanych formach;

b) spektaklu - „dramaturgizacja” i estetyzacja nawet zwyczajnych sytuacji; przewidywanie reakcji innych (publiczności) i dostosowywanie na tej podstawie własnych działan;

c) autoprezentacji - tendencja do zwiększania wysiłku wkładanego w tworzenie pozytywnego wizerunku własnej osoby;

d) designu - rosnące znaczenie atrakcyjności produktów; przy ocenie przedmiotów funkcja estetyczna równie ważna, jak użytkowa;

e) podglądactwa - potrzeba oglądania; udostępnianie szerszej publiczności sfer, które dotąd były ukryte (np. życie prywatne); zjawisko poszerzania widzialności.

Zdjęcia wykonuje się już prawie wszędzie i prawie wszystkiemu. Jednak to na polu turystycznym dochodzi do największej intensyfikacji tego zjawiska. Podróże od zawsze łączą się z potrzebą dokumentacji oraz upamiętnienia. Wyjazdy turystyczne stwarzają mnóstwo okazji do przeżycia czegoś, czym można pochwalić się przed rodziną lub znajomymi. Często to właśnie wakacje są okresem, z którego pochodzi najwięcej zdjęć, w ich czasie dochodzi do wydarzeń, które według podróżujących są warte uchwycenia. Nie powinno to dziwić, gdy weźmie się pod uwagę fakt, że sama turystyka definiowana jest w opozycji do codzienności. "Spojrzenie turysty” szuka tego, co nietypowe, nadzwyczajne, odmienne od przeżywanych zazwyczaj doświadczeń [...] Zdjęcia pozwalają uchwycić tę wyjątkowość, zamienić przeżycia w obrazy. S. SONTAG (2017) w następujący sposób analizuje zachowania turystów: „Podróżowanie dla przyjemności bez aparatu fotograficznego, wygląda nienaturalnie. Fotografie dostarczają niepodważalnego dowodu na to, że podróż się odbyła. [...] Fotografie dokumentują cykle konsumpcji prowadzonej poza wzrokiem rodziny, przyjaciół, sąsiadów".

Współczesny turysta potrzebuje aparatu, chce stworzyć relację z wyjazdu, aby móc przypomnieć sobie, czego doświadczył, oraz aby zaświadczyć o tym innym. Podróżnicze fotografie oddziałują również na turystyczne wyobrażenia o danym miejscu. Zanim ktoś pojedzie na zaplanowany wyjazd, najczęściej wie, jak wyglądają atrakcje, miasta czy obiekty, które odwiedzi. Określone miejsca mają swoje reprezentacje, które silnie definiują oczekiwania turystów. Podróżujący często jadą zobaczyć coś, co widzieli już na zdjęciach. Turystyczna fotografia nie tylko pozwala komunikować o sposobach spędzania wolnego czasu, ale również jest znaczącym czynnikiem determinującym podróżnicze wybory, a przez to również strukturę wyjazdów.

\section{SPOSOBY ANALIZOWANIA ZDJĘĆ Z MUZEÓW}

Muzea jako obiekty turystyki kulturowej także muszą zmierzyć się z problemem masowego wykonywania zdjęć. Niezależnie od tego, czy muzealnicy uznają to zjawisko za zagrożenie czy za szansę rozwoju, zdjęcia zamieszczane w portalach społecznościowych mogą być dla nich źródłem przydatnych informacji. Również dla badaczy tego typu fotografie stają się bardzo cennym materiałem. Na potrzeby niniejszej pracy autorka przeszła przez etap eksploracyjny analizy w portalu Instagram na podstawie zdjęć (oraz ich opisów) z Muzeum Narodowego w Krakowie². Uwzględniła nie tylko zdjęcia, na których są sami autorzy, ale wszystkie, które były oznaczone jako wykonane w muzeum. Wyodrębniła trzy sposoby rozpatrywania tego typu fotografii: 1) prezentowanie własnego wizerunku, 2) relacja $\mathrm{z}$ wizyty $\mathrm{w}$ muzeum, 3) interakcja z dziedzictwem. Kategorie te wskazują, jakiego rodzaju informacje można uzyskać, badając zdjęcia z muzeum, oraz z jakimi procesami i mechanizmami można je łączyć. Fakt, że autorka zaproponowała właśnie te trzy kategorie, nie oznacza wykluczenia innych rodzajów analizy. Stworzona typologia jest propozycją sposobu pracy z wykorzystaniem takich danych.

\section{ANALIZA ZDJĘĆ}

\subsection{PREZENTOWANIE WŁASNEGO WIZERUNKU}

Zdjęcia typu selfie oraz wszelkie udostępnianie fotografii z własną osobą opisywane są w wielu publikacjach jako przejaw „kultury narcystycznej”. Takie zdjęcia traktowane są w nich jako strategia zwracania na siebie uwagi, spełniania potrzeby pokazywania się innym (WAGNER 2015). W tym nurcie mówi się również o narcystycznym surfowaniu, czyli „kompulsyw- 
nej potrzebie pozostawiania po sobie wielu informacji w Sieci, ale także wyszukiwaniu informacji na swój własny temat" (SZPUNAR 2016). Przypisywanie internetowym fotografiom jedynie egoistycznych przesłanek wydaje się perspektywą niesłusznie wartościującą, a także zbyt powierzchownym potraktowaniem zjawiska. Posłużenie się koncepcją społeczeństwa autoprezentacji (BOGUNIA-BOROWSKA, SZTOMPKA, red. 2012) pozwala na obranie innej perspektywy. We współczesnym świecie jesteśmy bowiem odpowiedzialni za swój wizerunek. Procesy indywidualizacji sprawiły, że tworzenie odróżniającego się i wyjątkowego "projektu «ja»" jest wręcz obowiązkiem jednostki (JACYNO 2007, DzIUBAN 2013). Tożsamość w mniejszym stopniu przestaje być nadawana przez grupy, a w większym zależy od indywidualnych działań osób. Z tego faktu wynika konieczność samodzielnego budowania pozytywnego wrażenia, tworzenia ciekawego obrazu samego siebie. W innym przypadku można być oskarżonym o bezrefleksyjne i bierne funkcjonowanie w społeczeństwie.

Zdjęcia umieszczone $\mathrm{w}$ Internecie są idealnym narzędziem do tworzenia interesującego wizerunku. Także fotografie z muzeów służą demonstrowaniu swojej tożsamości. Osoby, które zdecydowały się opublikować zdjęcia z ekspozycji, stwierdziły, że zwiedzanie wystaw jest czynnością wpisującą się w kreowaną ${ }^{3}$ przez nie osobowość. Chociaż na poszczególnych profilach znajduje się czasami tak wiele zdjęć, że wydają się one wstawiane przypadkowo i chaotycznie, rzadko zdarza się, aby osoby umieszczały obrazy wyraźnie sprzeczne z ich wytworzonym wizerunkiem. Wybór udostępnianych fotografii, może nie zawsze świadomy, prezentuje jednak określony styl życia. Biorąc pod uwagę rosnące znaczenie autoprezentacji oraz specyfikę internetowych portali, cogito fotograficzne Soulagesa można uznać za niezwykle aktualną i trafną koncepcję. Zdjęcia umieszczane w Internecie stają się świadectwem, że jest się aktywnym. Są przede wszystkim dowodem atrakcyjnego spędzania czasu. Udostępnianie zdjęć oznacza, że właśnie przeżyło się coś, czym można podzielić się z szerokim gronem odbiorców. W portalach społecznościowych to właśnie fotografie są często warunkiem bycia zauważonym. Analizując upowszechniane zdjęcia $\mathrm{z}$ wizyt $\mathrm{w}$ muzeum, należy pamiętać, że dobór pozy, prezentowanego eksponatu czy stylistyki zdjęcia w zamierzeniu stanowią świadectwo autora.

Warto w tym miejscu zapytać, w jaki sposób zwiedzający przedstawiają siebie na prezentowanych zdjęciach. Analizowane fotografie najczęściej ukazują użytkowników w czasie wolnym. Wyglądają na zrelaksowanych, są ubrani w nieformalne stroje, często uśmiechnięci. Jednym z najbardziej typowych sposobów fotografowania się $\mathrm{w}$ muzeach jest zdjęcie na tle budynku lub eksponatów. Przybiera ono formę klasy- cznej pamiątki z wakacji, nieróżniącej się od fotografii z rodzinnego albumu. Osoba umieszczona zostaje na pierwszym planie, $\mathrm{w}$ tle interesujący obiekt (czasem dobrze widoczny, czasem mniej). Zdjęcie takiego typu, udostępniane na portalu społecznościowym, jest przede wszystkim dowodem odwiedzenia danego muzeum. Nawet szybko przeglądając fotografie, można łatwo rozpoznać, kto jest na zdjęciu oraz gdzie się znajduje.

Drugi, równie częsty typ zdjęć z wizyty w muzeum przedstawia użytkowników w trakcie zwiedzania. Na fotografiach osoby zostają zaprezentowane w momencie oglądania wystawy, gdy odwrócone tyłem lub bokiem do fotografa, spoglądają na konkretny eksponat. Zdarzają się również zdjęcia ukazujące osoby czytające materiały dla zwiedzających. W przypadku tego typu fotografii kładzie się duży nacisk na wykonywaną czynność, podkreśla się zainteresowanie i zaangażowanie danej osoby. Na podstawie tych zdjęć można wnioskować, że użytkownik udał się do muzeum, aby dowiedzieć się czegoś o dziedzictwie kulturowym. Informują one nie tylko, że ktoś wybrał się na wystawę, ale również, że był nią zaciekawiony. Wszystkie fotografie $\mathrm{z}$ muzeum publikowane w portalach społecznościowych sugerują zainteresowanie użytkowników sztuką bądź kulturą. Pokazują również, w jakich miastach dane osoby bywają oraz jak wypoczywają. Także to, w jakim muzeum wykonują zdjęcia, może być kwestią wzbogacającą ich wizerunek tworzony w Internecie.

\subsection{RELACJA Z MUZEUM}

Na podstawie zdjęć możliwe jest określenie wyobrażeń zarówno o samej instytucji muzeum, jak i o poszczególnych zwiedzanych placówkach. Fakt, że ludzie decydują się na udostępnienie fotografii przedstawiających ich na wystawie, świadczy o tym, że muzeum jest przez część użytkowników uznawane za miejsce, w którym warto bywać. Według nich wizytą $\mathrm{w}$ tej instytucji warto się pochwalić, traktują ją jako element, który może przyczynić się do stworzenia ich pozytywnego wizerunku. $Z$ pewnością muzeum jest miejscem kontaktu z kulturą, gdzie można dowiedzieć się czegoś nowego oraz zobaczyć unikatowe obiekty. Świadczą o tym wspomniane już zdjęcia, na których ukazano zarówno czynność oglądania wystawy, jak i opisy podkreślające wyjątkowość podziwianych przedmiotów. Możliwość zobaczenia oryginalnych eksponatów jest wciąż traktowana jako istotny element wizyty w muzeum.

Użytkownicy publikują zdjęcia z wystaw, nie ujmując tego jako nietypowe dla nich czy nadzwyczajne wydarzenie. Tego rodzaju fotografie funkcjonują raczej na takich samych zasadach co zdjęcia przedstawiające 
inne formy rozrywki czy edukacji. Fakt ten świadczy o tym, że zwiedzający nie uważają placówek za miejsca, gdzie wstęp ma jedynie ograniczone grono osób. W portalach społecznościowych muzeum nie przypisuje się elitarności, raczej określa się je jako instytucję, którą każdy (choćby od czasu do czasu) odwiedza. Warto podkreślić, że na wielu zdjęciach użytkownicy pojawiają się ze współzwiedzającymi. Wykonywanie fotografii w muzeum jest sytuacją, która często współdzielona jest z bliskimi. Wizyta na wystawie może więc być okazją do spotkania, nawiązywania kontaktu lub budowania relacji. Taka perspektywa podkreśla fakt, że muzeum może być przestrzenią nie tylko służącą do poznawania dziedzictwa kulturowego, ale również miejscem osobistych przeżyć oraz budowania więzi. Ten aspekt wizyt, który często umyka pamięci muzealników lub jest przez nich niedoceniany, ma duże znaczenie dla użytkowników.

Zdjęcia udostępniane przez zwiedzających nie pochodzą wyłącznie z sal wystawowych. Odwiedzający fotografują się także $w$ innych miejscach w muzeum, w przestrzeniach niepełniących ekspozycyjnych funkcji. Są to przykładowo kawiarnie czy muzealne sklepiki. Takie fotografie są cennym źródłem informacji o tym, jak zwiedzający korzystają z całego obiektu. Muzeum to dla nich nie tylko wystawa, ale również miejsce, gdzie mogą po zwiedzaniu odpocząć, podyskutować lub jeszcze pogłębić swoją wiedzę. Porównując zdjęcia z różnych placówek, można określić, jaki stosunek mają do nich zwiedzający. Publikowane zdjęcia wyraźnie ukazują różnice między poszczególnymi rodzajami muzeów. Dobrym przykładem są oddziały Muzeum Narodowego w Krakowie. Chociaż jest to jedna jednostka organizacyjna, to zdjęcia pokazują, że poszczególne obiekty wywołują odmienne wyobrażenia. Przykładowo gmach główny wiązany jest często z dużą wystawą czasową i ukazywany jako obiekt turystyczny, w którym można bardzo wiele nauczyć się, zobaczyć. Pawilon Czapskiego jest przedstawiany jako miejsce bardziej kameralne, gdzie odwiedzający spędzają wolny wieczór, przychodzą w dni powszednie posiedzieć w kawiarni. Użytkownicy uważają je za kierowane przede wszystkim do mieszkańców Krakowa.

\subsection{INTERAKCJA Z DZIEDZICTWEM}

Głównym celem ekspozycji jest prezentowanie elementów dziedzictwa kulturowego. Zwiedzający mogą bardzo odmiennie na nie reagować, np. zachwytem, zdziwieniem, oburzeniem czy znudzeniem. Goście muzealni charakteryzują się różnym poziomem wiedzy, zróżnicowanym gustem oraz odmiennymi doświadczeniami. W czasie wizyty uzyskują oni konkretne informacje na temat tego, co jest prezentowane na wystawie, ale również tworzą własne skojarzenia, narracje o eksponatach. Wbrew strategiom obieranym często przez twórców wystaw odbiór kultury nie przebiega w jeden odgórnie narzucony sposób, ale odbywa się na wielu bardzo zindywidualizowanych torach (JENKINS 2007). Widoczne jest to wyraźnie na zdjęciach publikowanych w portalach społecznościowych. Fotografie te pozwalają na pokazanie własnego spojrzenia na dzieła, na ukazanie tego, co zainteresowało danego użytkownika. Autorka wyodrębniła elementy interakcji z dziedzictwem, występujące na udostępnianych fotografiach z muzeów:

1) zwrócenie uwagi na szczegół - fotografowanie detali, często będących częścią większego obiektu (np. rzeźby, obrazu);

2) wykonywanie zdjęć z nietypowej perspektywy - eksponaty ukazywane z różnych kątów i miejsc, nieschematyczne ujęcia danego przedmiotu czy dzieła;

3) pozowanie z obiektem - odwzorowywanie scen z dzieł lub wkomponowywanie eksponatów w stworzoną scenę (np. rozmowy z rzeźbą);

4) dzielenie się refleksjami i przemyśleniami - najczęściej są one umieszczane w opisach zdjęć, niekiedy pojawiają się jako tekst naniesiony na zdjęcie w formie krótkiego hasła;

5) tworzenie kolażu zdjęć - zestawienie ze sobą kilku fotografii połączonych w jeden obraz;

6) tworzenie dzieł inspirowanych - wykonywanie rysunków, szkiców, grafik i obrazów konkretnych eksponatów lub prezentujących wizytę w muzeum;

7) tworzenie zdjęcia remiksowanego - tj. zdjęcia, które po wykonaniu zostaje modyfikowane poprzez wycinanie oraz wklejanie elementów z innych fotografii bądź obrazów.

Wszystkie te elementy służą zademonstrowaniu kwestii, które zaintrygowały i zainspirowały użytkowników. Zwiedzający na zdjęciach ukazują to, co ich rozbawiło czy skłoniło do przemyśleń. Eksponaty prezentowane są $\mathrm{w}$ nowych kontekstach, z autorskimi komentarzami i nietypowymi dla nich konotacjami. Wpisuje się to w tendencję nazywaną kulturą remiksu, w której istniejące dzieło staje się podstawą do tworzenia kolejnych, a treści kulturowe są nieustannie modyfikowane i na nowo interpretowane (NACHER, GULIK, KAUCZ 2011). H. Jenkins wskazuje na konwergencję, rozumianą przez niego jako „wyszukiwanie nowych informacji i tworzenie połączeń pomiędzy treściami rozproszonymi w różnych środkach przekazu" (JENKINS 2007). Część publikowanych zdjęć posiada cechy tego zjawiska. Można oczywiście potraktować takie fotografie jako banalną rozrywkę, lecz nie da się zaprzeczyć, że wykonując je, zwiedzający 
poznają dziedzictwo kulturowe, zaznajamiają się z nim, zaczynają się z nim identyfikować i na swój sposób je interpretować.

\section{ZAKOŃCZENIE}

Zastosowanie tradycyjnych koncepcji społecznych funkcji fotografii daje możliwość dogłębnego zrozumienia oraz precyzyjnego określenia specyfiki opisywanego zjawiska. Trzy wyodrębnione w niniejszym artykule perspektywy analityczne pozwalają natomiast spojrzeć na fenomen fotografowania się $\mathrm{w}$ muzeum z kilku odrębnych punktów widzenia. Pierwsza perspektywa, dotycząca budowania wizerunku, wpisuje to zjawisko $\mathrm{w}$ mechanizmy indywidualizacji oraz projektowania ,ja". Druga dostarcza wiedzę na temat odbioru muzeum. Umożliwia również porównywanie konkretnych placówek. Koncepcja interakcji z dziedzictwem wpisuje zjawisko w szersze procesy odbioru i dystrybucji kultury. Pozwala dowiedzieć się, jak zwiedzający interpretują napotykane treści oraz $\mathrm{w}$ jaki sposób nadają im znaczenia. Zdjęcia $\mathrm{z}$ muzeum są więc dla badaczy inspirującymi danymi na temat funkcjonowania współczesnych muzeów, zaś dla muzealników źródłem przydatnych informacji o własnej publiczności.

\section{PRZYPISY}

\footnotetext{
${ }^{1}$ Instagram - portal społecznościowy przeznaczony do publikowania zdjęć. Posty w nim mają formę fotografii z krótkim opisem oraz oznaczeniami - słowami kluczowymi poprzedzonymi znakiem \#.

2 Większość analizowanych zdjęć pochodzi z okresu od września do listopada 2017.

${ }^{3}$ Wyraz "kreowany" nie został tu użyty w negatywnym znaczeniu, nie oznacza sztucznie wytworzonej osobowości, stojącej $w$ opozycji do prawdziwej. Używanie tego terminu wynika z założenia, że badacz społeczny nie jest $\mathrm{w}$ stanie określić, czy prawdziwa tożsamość istnieje i jaka ona jest, ale ma dostęp jedynie do jej eksponowanych przejawów.
}

\section{BIBLIOGRAFIA}

BOGUNIA-BOROWSKA M., SZTOMPKA P. (red.), 2012, Fotospoteczeństwo. Antologia tekstów z socjologii wizualnej, Społeczny Instytut Wydawniczy Znak, Kraków.

BOURDIEU P., 2012, Społeczna definicja fotografii, [w:] M. Bogunia-Borowska, P. Sztompka (red.), Fotospołeczeństwo. Antologia tekstów z socjologii wizualnej, Społeczny Instytut Wydawniczy Znak, Kraków.

DZIUBAN A., 2013, Gry z tożsamością. Tatuowanie ciała w indywidualizującym się spoteczeństwie, Wyd. Naukowe Uniwersytetu Mikołaja Kopernika, Torun.

JACYNO M., 2007, Kultura indywidualizmu, Wyd. Naukowe PWN, Warszawa.

JENKINS H., 2007, Kultura konwergencji: zderzenie starych i nowych mediów, Wyd. Akademickie i Profesjonalne, Warszawa.

KONECKI K., 2005, Wizualne wyobrażenia. Główne strategie badaw$c z e$ w socjologii wizualnej a metodologia teorii ugruntowanej, "Przegląd Socjologii Jakościowej", I, 1.

MAŹNICA Ł., 2016, Selfie w muzeach - analiza zjawiska w kontekście działalności i roli społecznej muzeów, [w:] G. Stunża, K. Stachura (red.), Kultura od nowa. Badania - trendy - praktyka, Instytut Kultury Miejskiej, Gdańsk.

NACHER A., GULIK M., KAUCZ P., 2011, Post-teorie i re-praktyki. Wprowadzenie do remiksu, [w:] M. Gulik, P. Kaucz, L. Onak (red.), Remiks. Teorie i praktyki, Hub Wydawniczy Rozdzielczość Chleba, Kraków.

PIEJKO M., 2008, Skarby pamięci. Socjologiczna analiza fotografii rodzinnej, „Przegląd Socjologii Jakościowej”, IV, 3.

SONTAG S., 2017, O fotografii, Karakter, Kraków.

SOULAGES F., 2005, Estetyka fotografii. Strata i zysk, Universitas, Kraków.

SZPUNAR M., 2016, Kultura cyfrowego narcyzmu, Wyd. AGH, Kraków.

WAGNER E., 2015, Selfie society: Narcissism and the celebration of mediocrity, Kindle Edition.
Artykuł wpłynął:

15 lutego $2018 \mathrm{r}$

Zaakceptowano do druku:

14 maja $2018 \mathrm{r}$ 